\title{
Muscle Weakness Trunk
}

National Cancer Institute

\section{Source}

National Cancer Institute. Muscle Weakness Trunk. NCI Thesaurus. Code C78458.

A reduction in the strength of the trunk muscles. 